\title{
NrCAM modulates sonic hedgehog signalling by controlling smoothened translocation in the cilium
}

\author{
B Basu*, O Weeranantanapan, D Xenaki, A Furley \\ From Cilia 2014 - Second International Conference \\ Paris, France. 18-21 November 2014
}

\section{Objective}

Cerebellar development involves a spurt of proliferation in external granule layer (EGL) in response to shh, causing granule neuron precursors (GNPs) to proliferate. These cells subsequently differentiate into granule neurons in the inner granule layer (IGL). F3, a CNTN family molecule, can interact with $\mathrm{NrCAM}$ to switch GNPs from proliferation to differentiation. We aim to identify the role of $\mathrm{NrCAM}$ in the sonic hedgehog response in GNPs.

\section{Methods}

GNPs were extracted from wildtype and NrCAM mutant P5 cerebella using Percoll gradient centrifugation. Proliferation response to shh was measured using EdU in presence/absence of F3-Fc. GNPs treated with shh/SAG were stained with antibodies against Arl13b and smo to look for differences in cilia size and smo occupancy after different treatment times.

\section{Results}

$\mathrm{NrCAM}^{-/-}$and wildtype GNPs both proliferated equally in response to shh. F3 was found to block the proliferation response in wildtype but not in $\mathrm{NrCAM}^{-1-}$ GNPs. F3 also failed to affect proliferation in SmoA1 GNPs with a constitutively active smo suggesting that the F3-NrCAM mediated block lay upstream of Smo. NrCAM was detected in wildtype cilia and Smo localization was affected in $\mathrm{NrCAM}^{-/-}$GNPs. No differences in cilia length were observed.

\section{Conclusion}

Our results suggest that $\mathrm{NrCAM}$ affects shh-mediated proliferation by controlling smo movement into the cilium.

Published: 13 July 2015

Biomedical Science, University of Sheffield, Sheffield, UK

doi:10.1186/2046-2530-4-S1-P35

Cite this article as: Basu et al: NrCAM modulates sonic hedgehog signalling by controlling smoothened translocation in the cilium. Cilia 2015 4(Suppl 1):P35.
Submit your next manuscript to BioMed Central and take full advantage of:

- Convenient online submission

- Thorough peer review

- No space constraints or color figure charges

- Immediate publication on acceptance

- Inclusion in PubMed, CAS, Scopus and Google Scholar

- Research which is freely available for redistribution
() Biomed Central 